\title{
Application of environmental management system - ISO 14001: 1996, in urban environment and municipalities
}

\author{
${ }^{I^{*} J}$. Nouri and ${ }^{2}$ S. Toutounchian \\ ${ }^{1}$ Department of Environmental Health Engineering, School of Public Health and Institute of Health Research Center, \\ Tehran University of Medical Science, Tehran, Iran \\ ${ }^{2}$ Department of Environmental Management, Graduate School of the Environment, Science and Research Campus, \\ Islamic Azad Uuniversity, Tehran, Iran
}

\begin{abstract}
Application of environmental management system (EMS) in urban environment provides a city with orderliness, regularity, quietness and freshness environment. Besides, it contributes sustainable development and optimization in life level index of the city. If the whole urban districts design and establish an environmental management system ISO 14001, the development will be faster and more sustainable. Municipality of Tehran, District 22 has been found and started an activity under the command of Sterling Council of Iran Urbanization and Architecture in order to regenerate the urbanization concealed concepts and also to control and organize the excessive constructions in west and northwest of Tehran since 2000.

As a result of human undergoing development activities, the process of urbanization during many years has caused various environmental impacts. Thus, decision makers and managers considered urban sustainable development as a main strategy. District-22, has taken the required steps in providing sustainable development, safety and health of the organization and citizens in the related district. Environmental policy and commitment of top management (Mayor of the District-22) are to keep environmental conservation, in a well organized manner. In this study, dominant environmental aspects, impacts and legal requirements of the related activities and services are identified. Subsequently, environmental objectives and targets and also environmental management programs have been determined. Besides, training, internal and external communication, operational control, emergency preparedness and responsibility, obligations to follow environmental rules and achieving certification of ISO 14001; 1996 standard are the most important highlights at this study. The planning process, establishing and the method of operation has also been studied.
\end{abstract}

Key words: Environmental management system, ISO 14001 standard, Municipality of Tehran, District-22, sustainable development

*Corresponding Author, E-mail: nourijafar@hotmail.com

\section{Introduction}

The implementation and establishment of environmental management system (EMS) was first introduced following Rio de Janeiro Environment and Development Conference that resulted implementation of Agenda 21 (ANSI, 1999). International Standard Organization (ISO) developed the environmental management standard series (ISO 14000) which expanded worldwide (ISO, 1996). During recent years, human activities on growth and development have threatened and have had negative impacts on the environment. Considering the close relationship between issues of the environment and development and their inherent linkage, existing problems is expected to be moderated and solved by applying a suitable environmental management system.

Nowadays, with continuous establishment of environmental management system and its related standards more attention is being paid on ISO 14000 (Martin, 1998). The objectives of this standard are consistent of controlling urbanization and urban unsteadily unsustainable development, and also reducing the resulted environmental problems and improving the urban environmental sustainable development through the responsible organizations, such as municipalities and urban councils. Several environmental concerns have been applied in countries, such as Japan, Canada, Australia, China and Thailand (Bass, 
1999 and CEMS, 2002). This study has been conducted in Municipality of Tehran, District22 to meet the environmental management system requirement in order to be qualified for granting the ISO 14001 certificate. This case was conducted to prevent, reduce and control environmental adverse affects resulted from human and organization activities, and also qualifying to sustainable development, developing urban services and understanding the necessity of ISO 14001 in contributing sustainable development, safety and personnel health in this organization and in the whole District. Based on the recommendation of Iran Urbanization and Architectural Supreme Council, Municipality of Tehran, District - 22 municipality was formally established in 2000 to fulfill the objectives of reorganizing the ignored urban concepts, in order to accomplish suitable urban planning and reform illegal constructions within the city borders.

The District-22 is situated from the north and northwest to Alborz mountain chain, from the east to Kan River, from the south to Tehran-Karaj Freeway and from the west to the city of Karaj with an area of about 10,000 hectares. The District-22 is geographically centered between Tehran and Karaj as the metropolitans of the final prospect of development in Tehran. The potential and actual facilities, land structure, diversity and land virginity in this area are of great concern by urbanization experts and decision makers.
The related problems of this area influence the environment since the adequate attention is not paid to environmental legislation. Municipality of Tehran, District-22 consists of 6 localities and the organization structure of it includes the following authorities:

- Top management

- Assistants

- Committees

- Experts and technical commissions.

Figure 1 shows the situation of the District22 in City of Tehran.

Presently, about 400 employees work in one working shift at this District. Further more, there are also some contractors who are committed to their clients through the District22. Obviously, it is planned to increase the number of employees following the ongoing development of the district. The difference between District-22 and other districts in Tehran is in achieving research and development along with the routine trends. Organization structure of the Municipality of Tehran, District-22 has been modified in accordance with the environmental management system and it is shown in Figure 2.

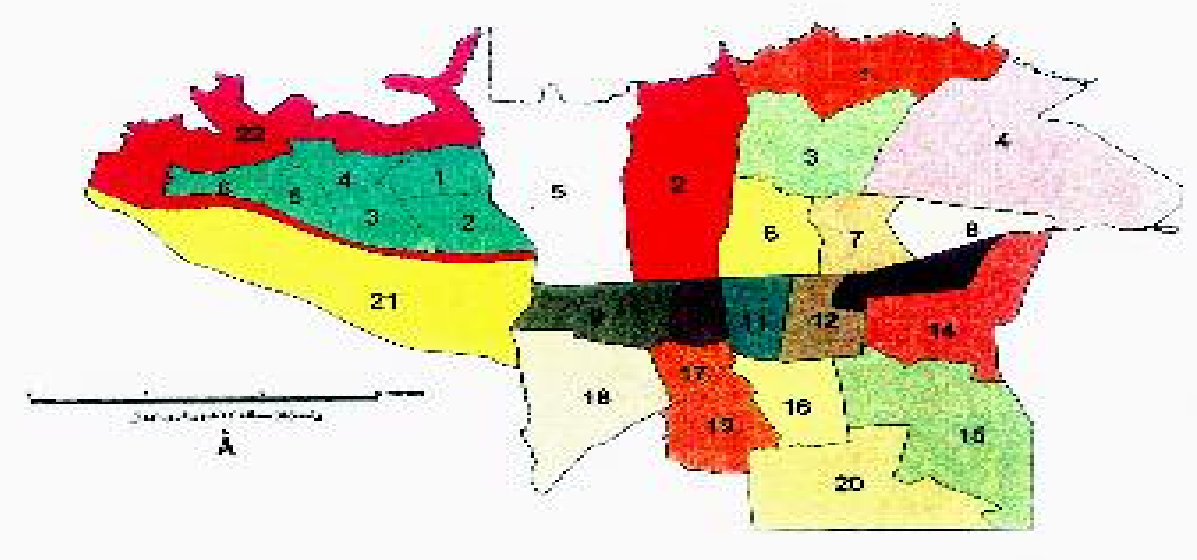

Figure 1: Situation of the District-22 comparing to other districts in Municipality of Tehran 


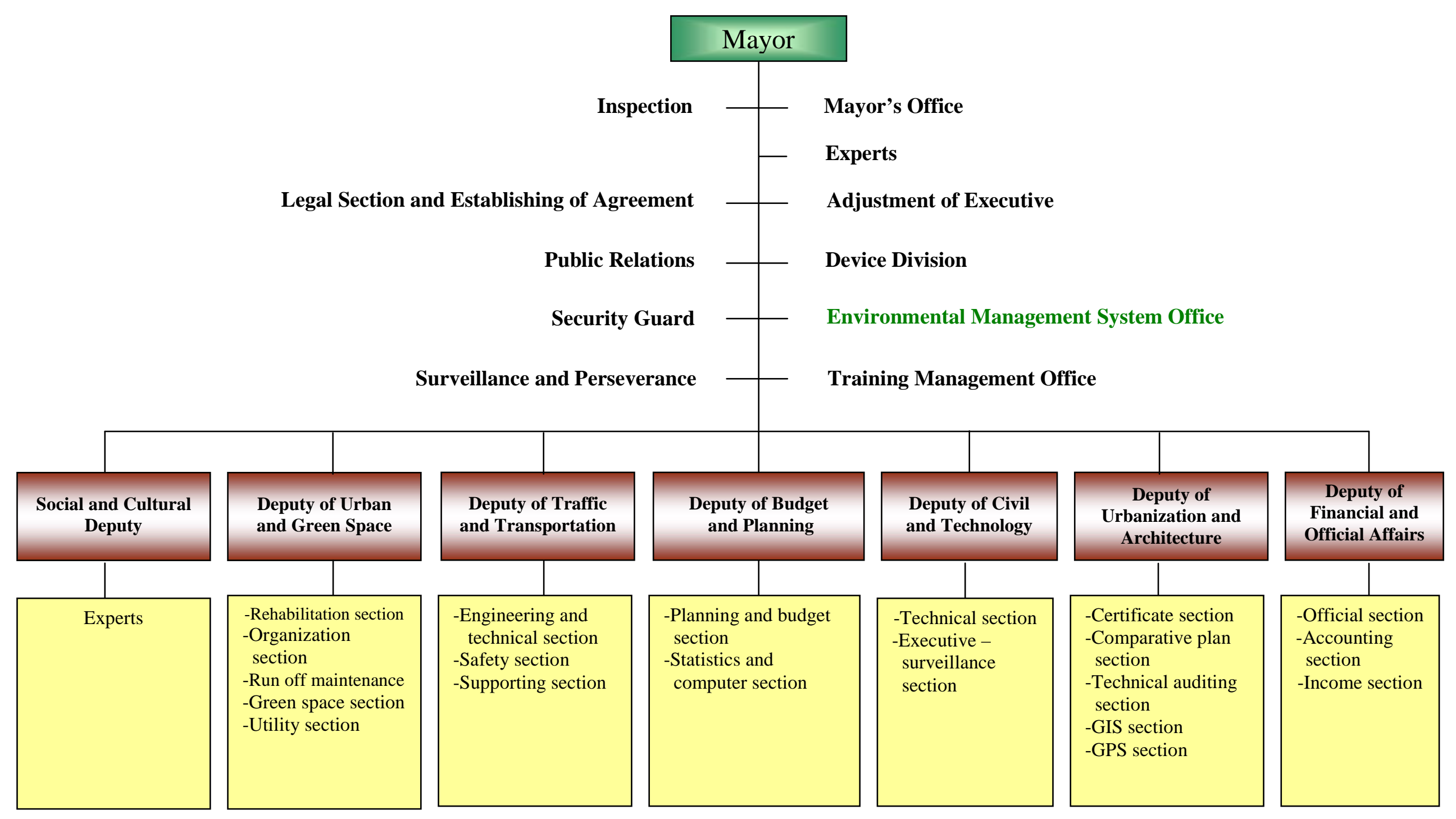

Figure 2: Organization structure of the Municipality of Tehran, District-22 


\section{Study Methodology}

This study was conducted as an applied project with the goal of establishment of environmental management system-ISO 14001 at Municipality of Tehran, District-22. In accordance with the ISO 14001 standard requirements the following steps were taken into action:

1. Commitment of top management

2. Designation of the manager representative and establishment of steering committee and implementation of EMS within the organization

3. Establishment of a committee to compile documentaries and records

4. Holding training workshops for managers and members of steering committee to introduce ISO 14000

5. Determining plans, implementation methods and constitutions for the environmental management system

6. Reviewing the present status of the organization

7. Defining the environmental policies at the organization

8. Studying environmental aspects and impacts

9. Determining the necessity of regulatory

10. Submitting environmental objectives and targets

11. Determining environmental management plans

12. Designing environmental training courses for employees of all levels

13. Implementation of the designed environmental management plans
14.Monitoring and control

15. Supervising documents and records

16. Preparing "Non Conformity Report" (NCR) and "Corrective Action Report" (CAR)

17. Auditing the environmental management system

18. Review of the top management

The execution of the above mentioned steps result in implementation of a managing system with the goal of preventing environmental problems. The establishment and performance model for the environmental management system in the District-22 is presented in the Figure 3.

Upon completion of the 18 steps, a certified company will take the necessary action for submission of ISO 14001 certificate, consisting of the following steps:

1. Pre-Auditing by the third party

2. Final-Auditing by the third party (external audit)

3. Receiving the ISO 14001 certificate by interested organization.

\section{Results and Discussion}

Implementation and establishment of EMS based on ISO 14001 for the Municipality of Tehran, District-22 resulted in the following points:

1. Determination of environmental policies of the Municipality of Tehran, District-22 as a fundamental and strategic of EMS

Box 1 shows the environmental policies of the Municipality of Tehran, District-22, which is outlined according to this study.

\section{Box 1: Environmental Policies of the Municipality of Tehran, District-22}

"Considering the will to achieve high standards for urban life and the necessity of protecting natural resources for the next generations and according to article 50 of the constitutions of Islamic republic of Iran in which environmental protection is considered a national responsibility, hereby the Municipality of Tehran, District-22, takes some actions to improve environmental conditions in the related district and establishes an environmental management system, ISO 14001, for the first time in Iran. The District-22 also commits to fulfill the following issues:

- Protection and conservation of natural urban resources and attempt to develop ecological benefits

- Environmental sustainable development and urban pollution prevention

- Commitment to meet the environmental laws and regulations in national, regional and international levels in accordance with Municipality of Tehran, District-22 activities and services

- Taking into consideration the opinions of all the interested parties and environmental experts in order to evaluate the environmental objectives and targets to ensure that they are in compliance with the environmental policies of the District

- Promotion of environmental conservation in the society by increasing public awareness of the employees and the citizens

The above-mentioned policy requires to be announced to all municipality employees and citizens. Additionally, the Mayor of Municipality of Tehran, District-22 believes that partnership of employees and citizens is a vital factor to establish the environmental management system in a sustainable way." 


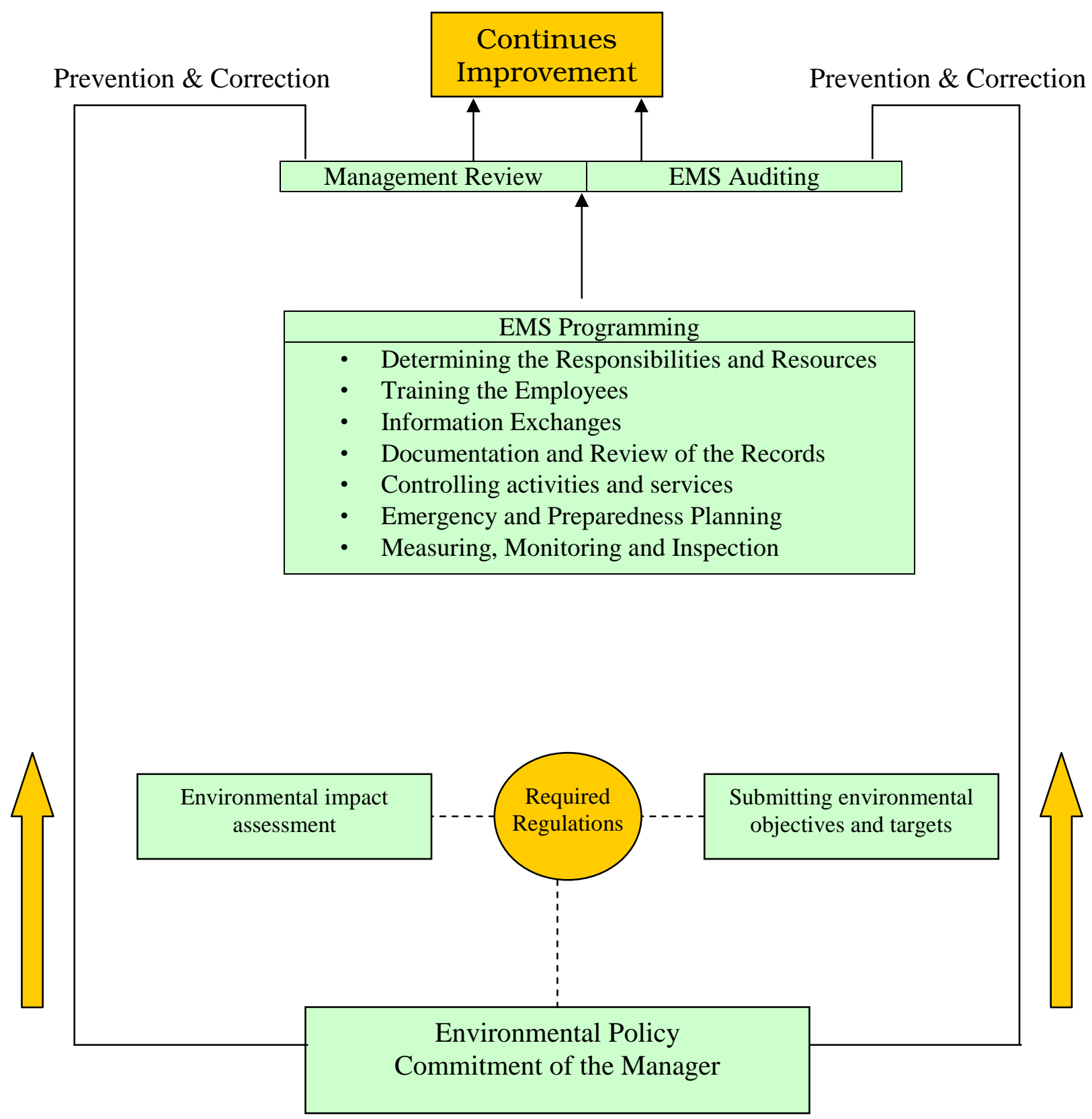

Figure 3: Model of establishment and performance of environmental management system in the Municipality of Tehran, District-22

2. The process of prioritization of environmental aspects for activities in the Municipality of Tehran, District-22 is shown in Table 1, in details.

3. Implementation of the objectives and targets of the Municipality of Tehran,
District-22 is constructed in accordance with environmental policy and issues, legal obligations, environmental aspects, financial, operational and technical abilities/facilities taking into consideration the opinions of interested parties and managers. 
Table 1: List of managing environmental impacts in Municipality of Tehran, District-22

\begin{tabular}{|c|c|c|c|c|}
\hline No. & $\begin{array}{c}\text { Environmental } \\
\text { Aspects }\end{array}$ & $\begin{array}{l}\text { Environmental } \\
\text { Impacts }\end{array}$ & Activities / Services & Comments \\
\hline 1 & $\begin{array}{l}\text { Emission of air } \\
\text { pollutants }\end{array}$ & Air pollution & $\begin{array}{l}\text {-Road and lane activities } \\
\text { (Tarring and paving) } \\
\text {-Passages cleaning }\end{array}$ & \\
\hline 2 & $\begin{array}{c}\text { Emission of } \\
\text { pollutants from } \\
\text { vehicles }\end{array}$ & Air pollution & -Organizing the traffic of vehicles & \\
\hline 3 & $\begin{array}{c}\text { Noise } \\
\text { production }\end{array}$ & Noise pollution & $\begin{array}{l}\text {-Road and lane activities } \\
\text { (Preparation, Tarring and paving) } \\
\text { - Organizing mobile sources }\end{array}$ & \\
\hline 4 & $\begin{array}{c}\text { Soil } \\
\text { contaminants } \\
\text { and erosion } \\
\text { causing factors }\end{array}$ & $\begin{array}{l}\text { Soil } \\
\text { contamination } \\
\text { and erossion }\end{array}$ & $\begin{array}{l}\text {-Road and lane activities } \\
\text { (Preparation, Tarring and paving) } \\
\text { - Collection and transportation of } \\
\text { wastes } \\
\text {-Crop-dusting and fertilization of } \\
\text { green space }\end{array}$ & \\
\hline 5 & Waste water & $\begin{array}{l}\text { Water pollution } \\
\text { and loss of } \\
\text { Natural } \\
\text { resources }\end{array}$ & $\begin{array}{l}\text {-Organizing employees health } \\
\text { condition, office activities } \\
\text {-Public services } \\
\text {-Passage cleaning }\end{array}$ & \\
\hline 6 & $\begin{array}{l}\text { Unsuitable } \\
\text { drink water } \\
\text { quality }\end{array}$ & $\begin{array}{l}\text { Water pollution } \\
\text { and negative } \\
\text { impacts on } \\
\text { health } \\
\text { conditions of } \\
\text { employees }\end{array}$ & $\begin{array}{l}\text {-Providing consumption water } \\
\text { (Office No.1) } \\
\text { - Providing consumption water of } \\
\text { the whole district }\end{array}$ & $\begin{array}{l}\text { Complains from people } \\
\text { and employees regarding } \\
\text { to adverse drinking } \\
\text { water quality }\end{array}$ \\
\hline 7 & $\begin{array}{l}\text { Usage of } \\
\text { chemicals and } \\
\text { hazardous } \\
\text { materials }\end{array}$ & $\begin{array}{l}\text { Environmental } \\
\text { pollution }\end{array}$ & $\begin{array}{l}\text {-Crop-dusting and fertilization of } \\
\text { green space } \\
\text {-Destroying the vermin }\end{array}$ & \\
\hline 8 & Radiations & $\begin{array}{l}\text { Adverse impacts } \\
\text { on employees } \\
\text { welfare }\end{array}$ & -Computer operation & \\
\hline 9 & Solid wastes & $\begin{array}{l}\text { Environmental } \\
\text { pollution and } \\
\text { threats to public } \\
\text { health }\end{array}$ & $\begin{array}{l}\text {-Official activities } \\
\text {-Performing all the executive, } \\
\text { service and civil activities } \\
\text {-Using of plastic and paper dishes } \\
\text {-Protecting the green space }\end{array}$ & $\begin{array}{l}\text { - Over production of } \\
\text { paper wastes } \\
\text { - Production of plastic } \\
\text { wastes and other wastes }\end{array}$ \\
\hline 10 & $\begin{array}{l}\text { Waste of energy } \\
\text { improper } \\
\text { energy } \\
\text { consumption }\end{array}$ & $\begin{array}{l}\text { Destruction of } \\
\text { natural } \\
\text { resources }\end{array}$ & $\begin{array}{l}\text {-Official activities } \\
\text {-All executive, service and civil } \\
\text { activities }\end{array}$ & $\begin{array}{l}\text { Water, electricity and } \\
\text { fuel consumption in the } \\
\text { organization buildings }\end{array}$ \\
\hline 11 & $\begin{array}{l}\text { Lack of public } \\
\text { health and } \\
\text { safety services }\end{array}$ & $\begin{array}{l}\text { Adverse impacts } \\
\text { on employees } \\
\text { health and } \\
\text { welfare }\end{array}$ & $\begin{array}{l}\text {-Performing all the executive, } \\
\text { service and civil activities } \\
\text {-Providing public services } \\
\text { (health and cleaning the sites) } \\
\text {-Existence of mice and vermin } \\
\text {-Adverse quality of food } \\
\text {-Health and safety of the } \\
\text { personnel }\end{array}$ & $\begin{array}{l}\text {-Observing personnel } \\
\text { health and cleanness } \\
\text {-Paying more attention } \\
\text { to health and safety }\end{array}$ \\
\hline 12 & $\begin{array}{l}\text { Modification of } \\
\text { environmental } \\
\text { views }\end{array}$ & $\begin{array}{l}\text { Modification of } \\
\text { landscape and } \\
\text { view pollution }\end{array}$ & $\begin{array}{l}\text {-Consequent of civil and service } \\
\text { activities and the green space }\end{array}$ & \\
\hline
\end{tabular}


The environmental objectives of Municipality of Tehran, District -22 are resulted as follow:

3.1. Reduction and control of emission for air pollutants

3.2. Reduction and control of air pollutants from the source of vehicles

3.3. Reduction and control of noise pollution

3.4. Reduction and control of soil pollution, soil restructure and erosion

3.5. Reduction and control of waste water and waste water treatment

3.6. Improving the quality of drinking water

3.7. Reduction and control of chemicals and hazardous materials

3.8. Control of adverse impacts on operators resulted from working with computer

3.9. Reduction of wastes, collection and sanitary or disposal of them

3.10. Reduction and improvement of energy consumption in the organization

3.11. Considering safety and improvement of safety concerns in the organization

3.12. Considering health issues and improvement of health concerns inside the organization

3.13. Considering employees welfare inside the organization

3.14. Environmental landscape improvement and reduction of environmental sight pollution

3.15. Improvement of planting in quality and quantity

3.16. Environmental public awareness and environmental conservation promotion in community

4. Programming executive management plans to fulfill the environmental objectives and targets and to meet standards of ISO 14001; such as the followings plans:

4.1. Environmental training course for employees

4.2. Emergency and preparedness plan

4.3. Health and quality improvement plan

4.4. Communication plan

4.5. A plan to improve energy consumption

4.6. A plan to control and reduce pollutions inside the organization

5. Defining executive methods and necessary procedures to establish environmental management system in Municipality of Tehran, District-22, as follows:

5.1. Procedure of labeling documentaries

5.2. Identification of the environmental aspects and impacts in practice

5.3. Identification of necessary legalizations at the stage of practicing the plan

5.4. Trainings executive plan

5.5. Communication executive plan

5.6. Documents control executive plan

5.7. Emergency and preparedness executive plan

5.8. Auditing, monitoring and measuring executive plan

5.9. Corrective actions and preventative programs executive plan

5.10. Records control executive plan

5.11. Environmental management system internal audit executive plan

5.12. Evaluating the authority of internal auditors of the environmental management system

5.13. Management review executive plan

5.14. Operation control executive plan

The documentations of this study were leaded to be verified that the outcomes of environmental management system fulfilled the requirements of DIN EN ISO 14000 certificate from DQS GmbH of Germany followed with the International Certification Network Certificate of IQNet which were granted and validated until 21. 09. 2006 (Figures4 and 5).

\section{Conclusion}

The present study reveals that, the implementation of environmental management system (EMS) regarding to ISO 14001 in the Municipality of Tehran, District-22 can have the following advantages:

- Continuous improvement of the environmental and occupational conditions, health and safety at Municipality of Tehran, Districe 22

- Compliance with the environmental legislations, lows and regulation at international, national and regional levels

- Satisfaction of citizens, employees and environmental interested parties and as a result, decrease in the number of received complains

- Improving the liability of the organization form point of view of the society and international organizations, by receiving the 


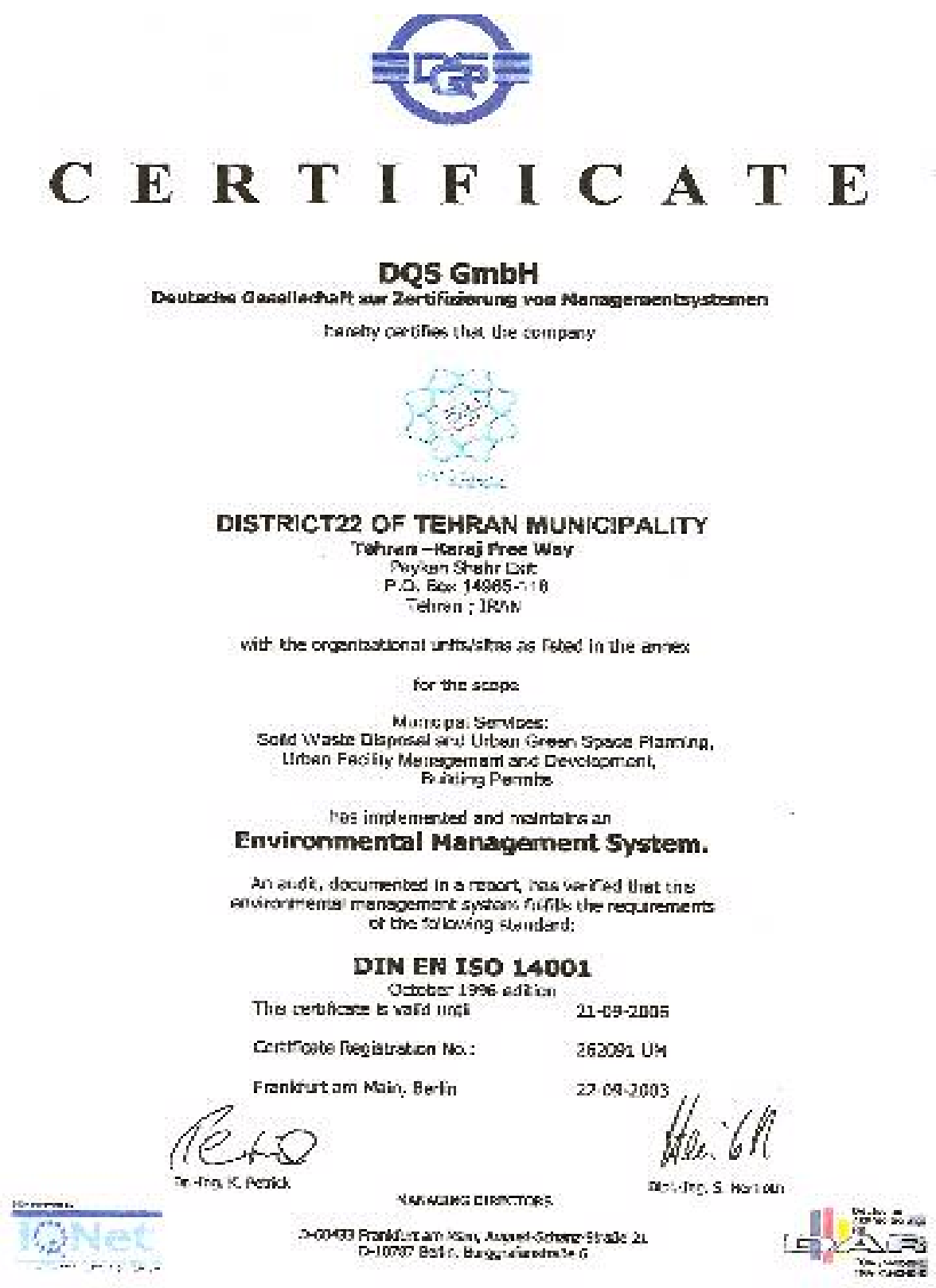

Figure 4: Certification of ISO 14001 in Municipality of Tehran, District-22, by DQS

certificates of ISO 14001 from the Qualified International Certified Organizations

- Improvement of management with elimination of unnecessary tasks

- Increase of the organization output and efficiency; fulfillment of green productivity through optimizing consumption of the existing resources, avoiding misusage of energy and reduction of wastes.

In order to improve serving capacity of the Districk 22 and improve occupational, health and safety conditions of its employees and increase the level of productivity following recommendation are highlighted:

- Implementation of quality management system (QMS) and ISO 9001; 2000

- Implementation of occupational, health and safety management system (OHSAS 18001)

- Implementation and establishment of integrated management system (IMS) 


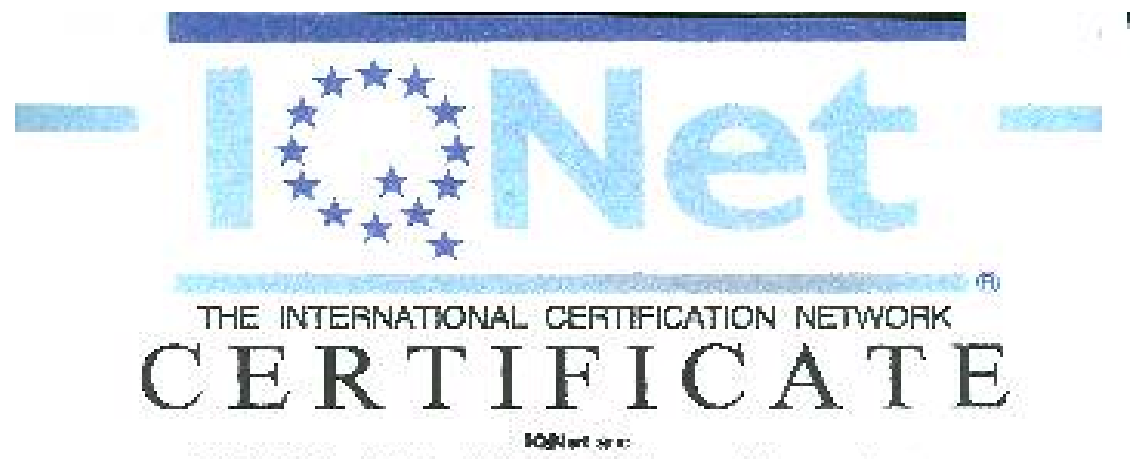

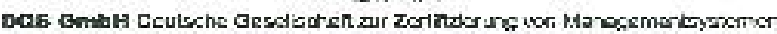
nerebycertifinot the nompunt

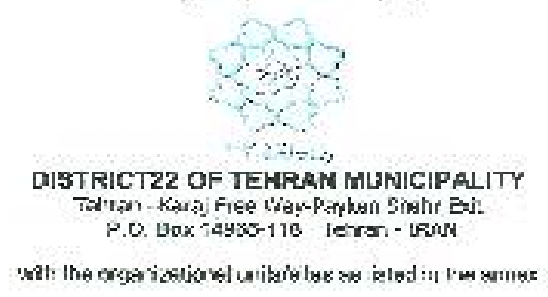

Irr the scope

Mritital Evaniss

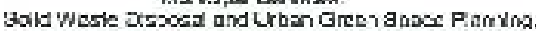

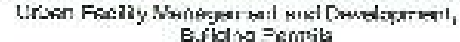

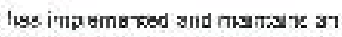

Ervironmental Management gybtem.

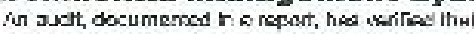

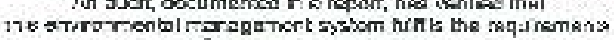

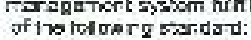

150 14001 = 1996

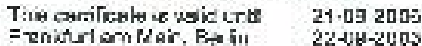

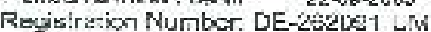
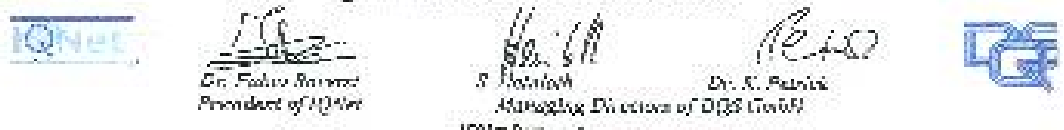

iove Pusmas?

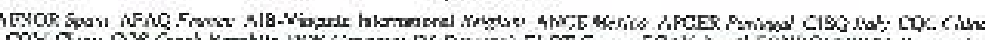

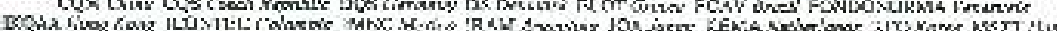

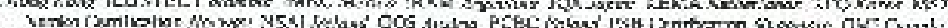

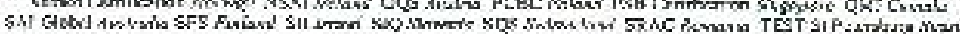

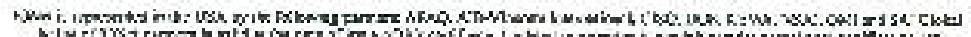

Figure 5: IQNet certification for ISO 14001 in Municipality of Tehran, District-22

Implementation and establishment of Systematization, Sanitary, standardiza- tion and self- discipline

- Benchmarking and compliance with standards

- Execution movements according to predetermined scenarios

\section{References}

ANSI Online ISO 14000 environmental management standards, document on the World Wide Web. http://web.ansi.org/pub/iso14000/, The American National Standard Institute, 1999

Bass, R., Environmental management goes global; What ISO 14001 means to local governments.
American Planning Association, California Chapter, 1999

Cities Environmental management Systems and ISO 14001: a view from Japan, 2002

International Standard Organization: ISO 14001 environmental management system-specification with guidance for use. I. S.O.; Switzerland, 1996

Martin, R., ISO 14001 Guidance manual center for environmental decision-making research, 1998

PISDES, ISO 14001 Environmental management system and public policy. Proceedings of a workshop Oakland, California, USA, 1999 

